\title{
Benign Cerebellar Pilocytic Astrocytomas in Children
}

\section{Çocukluk Çă̆ı Benign Serebellar Pilositik Astrositomaları}

\author{
Burcak BILGINER ${ }^{1}$, Firat NARIN ${ }^{1}$, Kader KARLI OGUZ², Sennur UZUN ${ }^{3}$, Figen SOYLEMEZOGLU ${ }^{4}$, \\ Nejat AKALAN ${ }^{1}$ \\ ${ }^{1}$ Hacettepe University, School of Medicine, Department of Neurosurgery, Ankara, Turkey \\ ${ }^{2}$ Hacettepe University, School of Medicine, Department of Radiology, Ankara, Turkey \\ ${ }^{3}$ Hacettepe University, School of Medicine, Department of Anaesthesiology and Reanimation, Ankara, Turkey \\ ${ }^{4}$ Hacettepe University, School of Medicine, Department of Pathology, Ankara, Turkey
}

Correspondence address: Burcak BILGINER / E-mail: burcak@tr.net

\begin{abstract}
AIM: Cerebellar astrocytomas are benign tumors of the central nervous system. They represent $10 \%$ of all pediatric intracranial brain tumors and $30 \%$ of all pediatric posterior fossa tumors especially in the first two decades of life.

MATERIAL and METHODS: Material and Methods: We reviewed the medical records of patients; age at the time of surgery, pre- and post operative magnetic resonance imaging (MRI), localisation of the tumor, hydrocephalus, surgical approach, pre- and post operative neurological status, post operative adjuvant therapy and outcome were documented.

RESULTS: The male to female ratio was 20/11. Age at the time of evaluation ranged from 3 to 23 years. Age at the time of surgery ranged from 1 to 18 years. Follow-up duration after surgery was $1-12$ years. $55 \%$ of these tumors were located at the cerebellar vermis and $45 \%$ were at the cerebellar hemispheres. Complete surgical resection was done in $74 \%$ of these patients. 5 patients had a second operation because of residual tumor. Ventriculoperitoneal shunt insertion was performed in 3 of 31 patients because of symptomatic hydrocephalus and 1 patient had an endoscopic third ventriculostomy pre-operatively. $90 \%$ of these patients had no neurological sequelae at follow-up evaluation.
\end{abstract}

CONCLUSION: Cerebellar astrocytomas are benign tumors where total resection is possible in the majority of cases with an excellent outcome. KEYWORDS: Pilocytic astrocytoma, Cerebellum, Brain tumor, Childhood, Astrocytomas

öz

AMAÇ: Serebellar astrositomalar santral sinir sisteminin iyi huylu tümörleridir. Özellikle hayatın ilk iki on yılındaki çocukluk çağı posterior fossa tümörlerinin \%30'unu, çocukluk çağı intrakranyal beyin tümörlerinin ise \%10'unu oluştururlar.

YÖNTEM ve GEREÇ: Bu çalışmada, 1997-2008 yılları arasında cerrahi olarak tedavi edilmiş 31 hasta incelendi. Bu hastaların hastane kayıtları incelenerek cerrahi anındaki yaş, ameliyat öncesi ve sonrası manyetik rezonans görüntüleri, tümör lokalizasyonu, hidrosefali varlığı, cerrahi girişim şekli, ameliyat öncesi ve sonrası nörolojik tablo, ameliyat sonrası aldığı ek tedaviler ve sağkalım incelendi.

BULGULAR: Erkek/kız oranı 20/11 idi. Araştırma esnasındaki yaş dağılımı 3-23 idi. Operasyon esnasındaki yaş dağılımı 1-18 idi. Cerrahi tedavi sonrasındaki izlem süresi 1 ile12 yıl arasında değişiyordu. Bu tümörlerin \%55'i serebellar vermiste, \%45’i ise serebellar hemisferlerde lokalize idi. \%74 hastada tam cerrahi rezeksiyon yapıldı. Beş hasta geride tümör kalması nedeni ile tekrar opere edildi. Cerrahi öncesinde 3 hastaya hidrosefali nedeniyle ventriküloperitoneal şant , 1 hastaya ise endoskopik üçüncü ventrikülostomi yapıldı. İlemde \%90 hastada herhangi bir nörolojik sekele rastlanmadı.

SONUÇ: Serebellar astrositomlar pekçok vakada tam rezeksiyonun mümkün olabildiği oldukça iyi seyirli tümörlerdir.

ANAHTAR SÖZCÜKLER: Pilositik astrositoma, Serebellum, Beyin tümörü, Çocukluk çağı, Astrositoma

\section{INTRODUCTION}

Juvenile pilocytic astrocytoma of the cerebellum in children is traditionally accepted as a cystic tumor with a mural nodule showing a favorable prognosis after resection. While magnetic resonance imaging (MRI) provided invaluable information for diagnosis and better evaluation of treatment results, it also enabled to differentiate subgroups of low grade astrocytomas which have different radiological appearance and location compared to the classical form. The aim of this study is to explore whether there is any clinical relevance of the different location (hemisphere or vermis) or texture (solid or cystic) of the cerebellar pilocytic astrocytomas with identical histopathological features $(3,10,11,22)$.

\section{MATERIAL and METHODS}

We performed a retrospective study of 31 patients who were surgically treated for cerebellar pilocytic astrocytomas at the Department of Neurosurgery of the Hacettepe University 
School of Medicine between 1997 and 2008. All patients had to have pre- and postoperative follow-up MRIs and pathologically proven cerebellar pilocytic astrocytoma. We reviewed the medical records of patients for age at the time of surgery, pre- and postoperative MRIs, localization of the tumor, presence of hydrocephalus, surgical approach, pre- and post operative neurological status, postoperative adjuvant therapy and outcome. Postoperatively patients were followed up at 1, 3 and 6 months, at 1 year and then at yearly intervals. MRI studies included sagittal and axial T1-weighted (W) spin-echo (SE) (TR/TE; 450-600 /15-20 ms) imaging, axial, and coronal T2-W turbo SE imaging (TR/TE; 4000/100 ms) and post-Gadolinium (Gd) axial and coronal T1-W SE with the same parameters of pre-contrast T1-W images. All the sequences had a slice thickness of $5 \mathrm{~mm}$ with an interslice gap of $1 \mathrm{~mm}$ and included 20 slices covering the whole brain.

Location (vermis or cerebellar hemisphere) and texture (solid or cystic) of the tumor were re-evaluated from these examinations.

Results of all pathological examinations were reviewed, and cases of anaplastic astrocytoma and glioblastoma multiforme were excluded from the study. Microscopic slides were prepared from formalin-fixed paraffin-embedded tissues. Sections were cut $4 \mu \mathrm{m}$ thick and stained with hematoxylin and eosin stain. Immunohistochemical staining for synapthophysin, glial fibrillary acidic protein, neuronal nuclear antigen and Ki-67 was performed in all cases.

No premedication was prescribed to any children before anaesthesia. Full monitorisation consisting of electrocardiography, pulse oxymetry, end tidal carbon dioxide, temperature measurements and urinary catheter placement was applied to all patients. After the endotracheal intubation, an invasive radial arterial line and subclavian catheter were also inserted. Anaesthesia was maintained with sevoflurane (2\%), and air and oxygen mixture (50\%) with the combination of remifentanil infusion $(0.05-0.1 \mathrm{mg} / \mathrm{kg})$.

\section{RESULTS}

\section{Clinical features}

There were 31 pediatric patients who met the inclusion criteria of this study: to have cerebellar astrocytoma, to have a contrast-enhanced pre-operative MRI as well as postoperative follow-up MRI for at least 12 months. Male to female ratio was 20/11. Age at the time of evaluation ranged 3-23 years (mean, $12.16 \pm 5.26$ years), age at the time of operation ranged $1-19$ years (mean, $8.29 \pm 4.91$ years). Followup duration was $1-12$ years (mean, $4.54 \pm 2.59$ years). The most common presenting symptom was headache $(67,7 \%)$. Other clinical symptoms at presentation included vomiting $(64,5 \%)$, gait disturbance $(48,3 \%)$, neck stiffness $(16,1 \%)$, diplopia $(6,4 \%)$, visual impairment $(3,2 \%)$ and developmental delay $(3,2 \%)$. Neurological findings at the initial examination were papilledema $(70,9 \%)$, ataxia $(54,8 \%)$, nystagmus $(22,5 \%)$, dysmetria $(16,1 \%)$, diplopia $(9,6 \%)$, dysarthria $(3,2 \%)$ and dysdiadochokinesia (3,2\%). Duration of symptoms ranged from 1 week to 7 months. The presenting symptoms and the neurological findings of the patients at initial examination are summarized in Table I.

\section{Neuroimaging}

Eight patients (26\%) had solid tumor (Figure $1 A, B, C$ ) on MRI and $23(74 \%)$ patients had cystic tumor (Figure $2 A, B, C$ ) with a mural nodule. The pilocytic astrocytomas involved the vermis in $17(55 \%)$ patients, $13(76 \%)$ of these patients had cystic and $4(24 \%)$ of them had solid vermian tumor. Brain MRIs showed hemispheric lesion in 14 (45\%) patients, 9 (64\%) in the left and $5(36 \%)$ in the right. Of these 14 patients $10(71 \%)$ had cystic cerebellar with a mural nodule and 4 (29\%) had solid cerebellar tumor.

\section{Pathology}

World health organisation (WHO) classification of tumors of the central nervous system (CNS) is used to classify the cerebellar neoplasms (17). According to the WHO guide lines neoplasms that are histologically characterized by a biphasic pattern with compacted bipolar cells and loosetextured multipolar cells associated with Rosenthal fibers and eosinophilic granular bodies, are diagnosed as pilocytic astrocytoma WHO grade 1. Glial fibrillary acidic protein (GFAP) immunoreactivity is detected especially in the bipolar cells. Ki-67 labeling index is generally lower than $1 \%$.

\section{Presence of Hydrocephalus}

Hydrocephalus was present in 24 (77,5\%) patients preoperatively. Lethargy due to obstructive hydrocephalus required surgical therapy at 4 patients. In 3 of these patients ventriculoperitoneal shunt insertion was done. Endoscopic third ventriculostomy was the treatment of choice in 1 patient.

Table I: Presenting Symptoms and Signs in 31 Patients

\begin{tabular}{l|r|r|}
\hline Presentation & & \\
Symptoms & 21 & 67,7 \\
Headache & 20 & 64,5 \\
Vomiting & 15 & 48,3 \\
Gait disturbance & 5 & 16,1 \\
Neck stiffness & 2 & 6,4 \\
Diplopia & 1 & 3,2 \\
Visual impairment & 1 & 3,2 \\
Developmental delay & & \\
Signs & 22 & 70,9 \\
Papilledema & 17 & 54,8 \\
Ataxia & 7 & 22,5 \\
Nystagmus & 5 & 16,1 \\
Dysmetria & 3 & 9,6 \\
Diplopia & 1 & 3,2 \\
Dysarthria & 1 & 3,2 \\
Dysdiadochokinesia & &
\end{tabular}




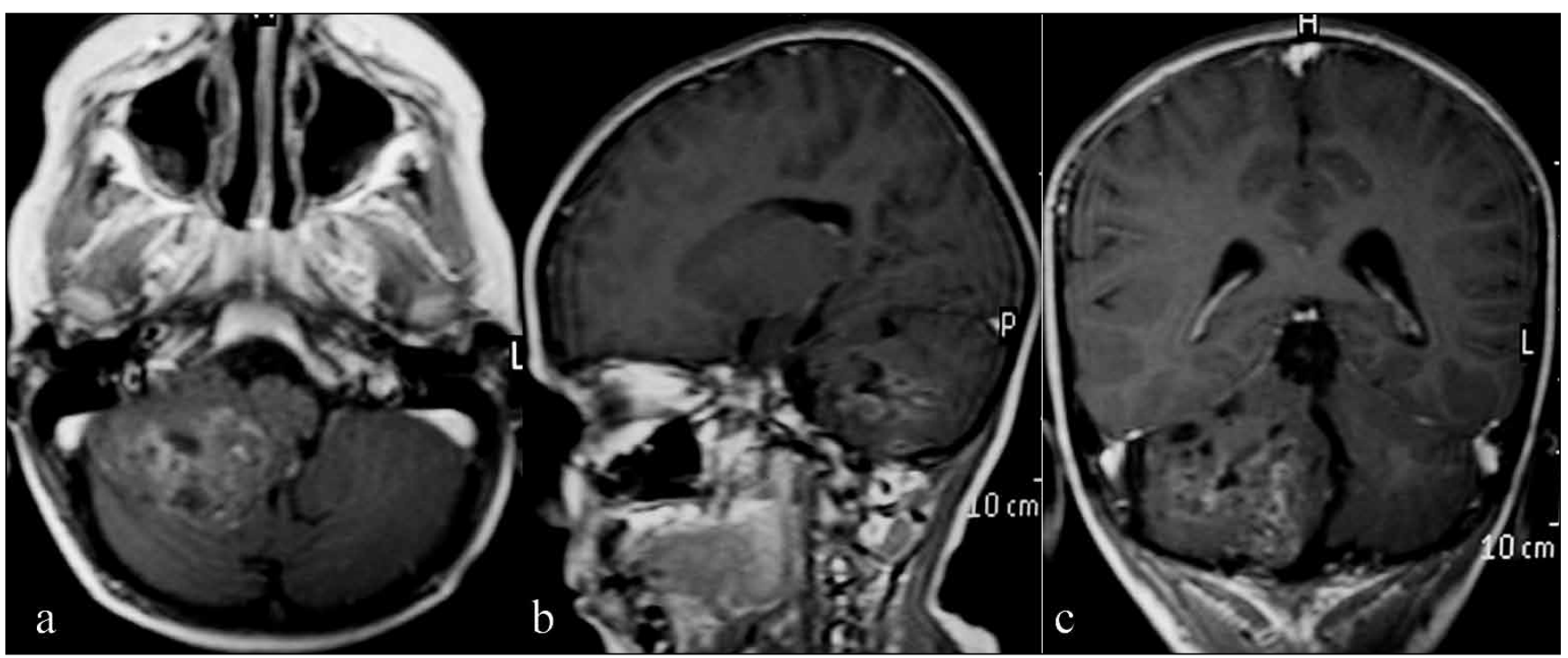

Figure 1: An inhomogenous solid mass in the right cerebellar hemisphere with indistinct margins is observed on axial A), sagittal B) and coronal C) postcontrast T1W images. The right foramen of Luschka is obliterated by the mass. Please note that the lateral ventricles are of normal size.

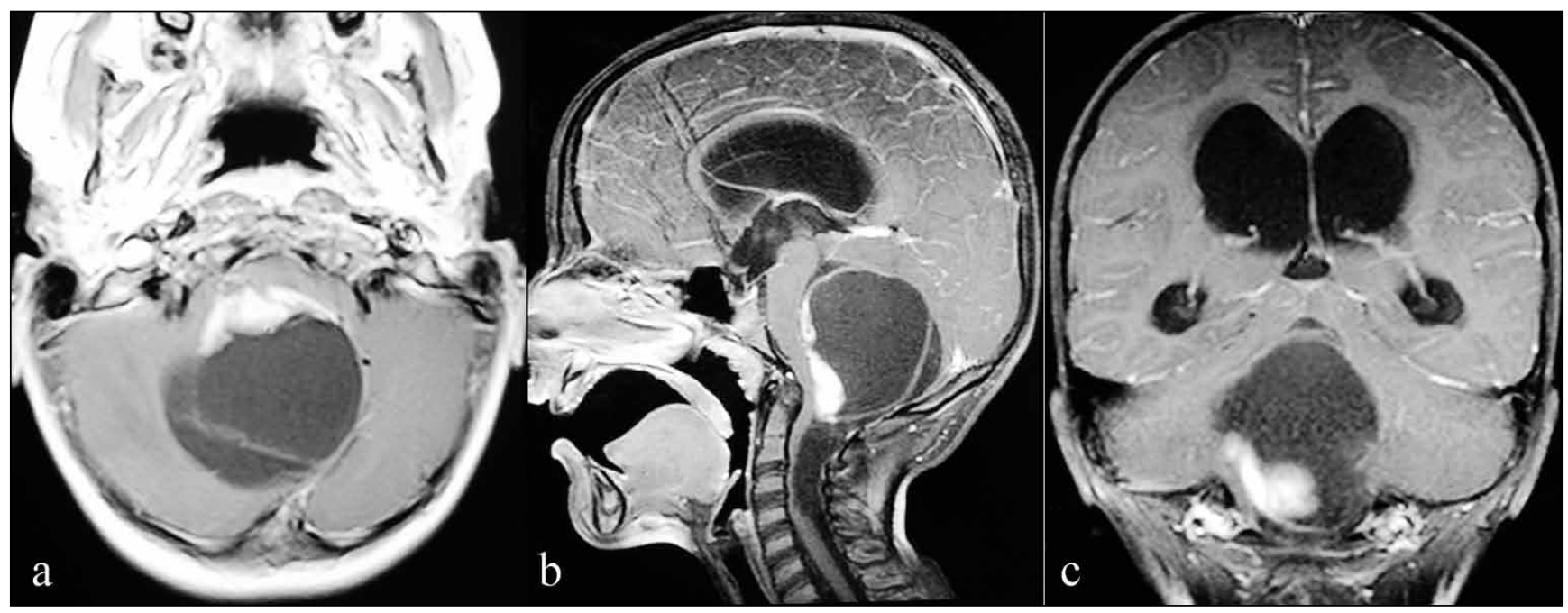

Figure 2: A large cystic midline mass with anteriorly located enhancing solid nodule is seen on axial A), sagittal B) and coronal C) postgadolinium T1-weighted (W)images. The mass compresses on the upper vermis,brain stem and 4th ventricle resulting in triventricular hydrocephalus $(B, C)$.

At postoperative period none of the patients required surgical treatment for hydrocephalus.

\section{Tumor resection}

All patients were placed in the sitting position. Suboccipital craniotomy without removal of the arch of $\mathrm{C} 1$ was performed for all vermian tumors. A suboccipital paramedian incision was performed on the side of the tumor for hemispheric tumors.

Our intention was to perform total tumor resection in all patients except 2 because of cerebellar peduncle involvement, but the tumor was resected totally in 23 (74\%) of cases and subtotal resection was done in $8(26 \%)$ of patients. Residual tumor was identified in early post operative MRIs. No persistent hydrocephalus was detected at post-operative period. Five of eight patients had gone to second operation due to growth of residual tumor and gross total resection was done in these 5 patients. Two patients with incomplete resection during the first surgical approach had undergone postoperative radiotherapy.

Ataxia (16\%), dysphagia (9,6\%), mutism (9,6\%) and CSF fistula $(6,4 \%)$ were seen as an early postoperative complications (Table II). There were no postoperative deaths.

\section{DISCUSSION}

There are several factors such as the extent of surgical resection, brain stem involvement, recurrences, the role of radiotherapy 
Table II: Early Postoperative Complications

\begin{tabular}{l|c|c|}
\hline Complication & No. of patients & $\%$ \\
\hline Ataxia & 5 & 16 \\
\hline Dysphagia & 3 & 9,6 \\
\hline Mutism & 3 & 9,6 \\
CSF fistula & 2 & 6,4 \\
\hline
\end{tabular}

and localization of the tumor on patient outcome after treatment. Improvement in imaging and surgical techniques has resulted in improved morbidity and mortality rates. Most authors agree that complete surgical resection of the tumor is an important prognostic factor on tumor recurrence and survival rates $(1,8,13,16,18)$. Gjerris et al. (9) report a survival rate of $94 \%$ and Zakrzewski et al. (23) report $88 \%$ for 25 -year survival. However, there are also some reports on recurrence of cerebellar astrocytomas after complete surgical excision $(2,11,15)$. Our percentage for complete surgical resection after first surgery was $74 \%$ and all of these patients were tumor free after a mean follow-up of 4.54 years.

In general, diagnosis of cerebellar pilocytic astrocytomas takes a long period of time because of slow progression of the tumor. Primary presenting symptoms are related to hydrocephalus because of the obstruction of cerebrospinal fluid (CSF) pathway by the tumor and symptoms related to cerebellar infiltration. Comparison of the presenting symptoms and neurological findings did not reveal any significant difference between the symptoms related to hydrocephalus or cerebellar infiltration according to tumor localization or radiological appearance.

Austin et al. (2) reported a rate of $23 \%$ for the incidence of tumor recurrence in their combined series. Due-Tonnessen et al. (5) observed growth of the residual tumor in $27 \%$ of their patients. We have not seen any tumor recurrence in our series, but 8 of 31 patients had residual tumor after their first surgery. Five of these patients had a second operation for the residual tumor and all had gross total resection after this surgery according to imaging findings. Spontaneous involution of the residual tumor after primary resection for cerebellar pilocytic astrocytomas has also been reported $(4,5,21)$. Our approach in treating these patients depends on residual tumour size on postoperative MRI, clinical status of the patients and risk of the re-surgical procedure. We decide on a second operation if the tumor is accessible with a low surgical risk, but we can choose to follow these patients clinically as well as with serial MRIs if there is a high morbidity or mortality risk for residual tumor like our patient who had brain stem involvement,.

The effect of radiation therapy is controversial in the literature. According to the majority of the published studies, the longterm prognosis of patients treated with surgery alone did not change remarkably than those treated with surgery and radiation therapy $(6,7)$. Radiotherapy has several side effects on the developing brain and there are also some case reports regarding malignant transformation of low grade cerebellar astrocytomas after being radiated $(12,19)$.

Postoperative radiotherapy was used in two of our patients whose tumors had been incompletely excised during the first surgical intervention due to brain stem involvement. We did not observe any improvement in prognosis after postoperative radiotherapy like Sgouros et al. reported (20), but our number of patients was too small for statistical analysis. We prefer to perform second surgery for patients with residual tumor if it is possible because of the potential risks of radiotherapy.

On MRI, 8 patients had solid and 23 patients had cystic tumors in our series. According to tumor localization, 17 of these tumors were localized at the cerebellar vermis. Of these 17 patients 13 had a midline cystic tumor with a mural nodule and 4 of the patients had a solid vermian tumor. Three of 4 patients with a solid vermian tumor also had brain stem involvement. Two of these patients had undergone radiotherapy because of residual tumor after the first operation. The rest of the patients had cerebellar hemispheric tumors. Of these 14 patients, 10 had a cystic tumor and 4 had a solid tumor. Five of these patients underwent a second operation for residual tumor. Our surgical mortality was $0 \%$ and total tumor resection was achieved in $90 \%$ of the patients with a combination of first and second surgeries.

In general, total tumor resection was higher in patients where the tumor did not invade the brain stem and the floor of the fourth ventricle. According to nature of lesion it seems that cystic lesions in our series have a more favorable outcome than solid tumors as brain stem involvement increases the morbidity of solid lesions.

Complete removal of the cystic lesions has been controversial in the literature. Sgouros et al. (20) reported that the outcome in cystic tumors is not so much different between total and subtotal resections. Pencalet et al. (16) reported that they remove any macroscopically apparent abnormal cyst wall because of the risk of recurrence. In our series, gross total resection was performed for all cystic tumors and we resected the cyst wall if contrast enhancement had been observed in the preoperative MRI.

Leptomeningeal dissemination and malignant transformation of cerebellar astrocytomas have also been reported $(4,14)$ in the literature, but we have not seen any tumors with these abnormalities.

We do not know the long term survival rates in our series, but cystic tumors had better outcome from the solid ones independent of the localization. Permanent neurological deficits were more often observed among vermian tumors. Brain stem involvement has a less favorable outcome and is the most prognostic factor. Shunting of hydrocephalus preoperatively is not always necessary.

In conclusion, a median follow-up period of 4,54 years provided no straightforward difference between solid and cystic pilocytic tumors or between cerebellar hemispheric or 
vermian tumors. While the likelihood of achieving gross total resection seemed to be less possible in solitary forms, it is yet unclear whether this is crucial for the long-term prognosis.

\section{REFERENCES}

1. Abdollahzadeh M, Hoffman HJ, Blazer SI, Becker LE, Humphreys RP, Drake JM, Rutka JT : Benign cerebellar astrocytoma in childhood: Experience at the Hospital for Sick Children 1980-1992. Child's Nerv Syst 10: 380-383,1994

2. Austin EJ, Alvord EC Jr: Recurrences of cerebellar astrocytomas: A violation of Collins' law. J Neurosurg 68:41-47,1988

3. Desai KI, Nadkarni TD, Muzumdar DP, Goel A : Prognostic factors for cerebellar astrocytomas in children: A study of 102 cases. Pediatr Neurosurg 35:311-317,2001

4. Dirven CM, Mooij JJ, Molenaar WM: Cerebellar pilocytic astrocytoma: A treatment protocol based upon analysis of 73 cases and a review of the literature. Childs Nerv Syst 13(1): $17-23,1997$

5. Due-Tønnessen BJ, Helseth E, Scheie D, Skullerud K, Aamodt G, LundarT: Long-term outcome after resection of benign cerebellar astrocytomas in children and young adults (0-19 years): report of 110 consecutive cases. Pediatr Neurosurg 37(2):71-80,2002

6. Ferbert A, Gullotta F: Remarks on the follow up of cerebellar astrocytomas. J Neurol 232:134-136,1985

7. Garcia DM, Latifi HR, Simpson JR, Picker S: Astrocytomas of the cerebellum in children. J Neurosurg 71:661-664,1989

8. Garcia DM, Marks JE, Latifi HR, Kliefoth AB: Childhood cerebellar astrocytomas: Is there a role for postoperative irradiation? Int J Radiat Oncol Biol Phys 118: 815-818,1990

9. Gjerris F, Klinken L: Long term prognosis in children with benign cerebellar astrocytoma. J Neurosurg 49:179-184,1978

10. Gol A, Mc Kissock W: The cerebellar astrocytoma. A report of 98 verified cases. J Neurosurg 16:278-296,1959

11. Ilgren EB, Stiller CA: Cerebellar astrocytomas. Therapeutic management. Acta Neurochir (Wien) 81:11-26,1986
12. Kleinman GM, Schoene WC, Walshe TM 3rd, Richardson EP Jr: Malignant transformation in benign cerebellar astrocytoma. Case report. J Neurosurg 49(1):111-118,1978

13. Lapras C, Patet JD, Lapras C Jr, Mottolese C: Cerebellar astrocytomas in childhood. Child's Nerv Syst 2:55-59,1986

14. Morikawa M, Tamaki N, Kokunai T, Nagashima T, Kurata H, Yamamoto K, Imai Y, Itoh H: Cerebellar pilocytic astrocytoma with leptomeningeal dissemination: Case report. Surg Neurol 48(1):49-51,1997

15. Pagni CA, Giordana MT, Canavero S: Benign recurrence of a pilocytic cerebellar astrocytoma 36 years after radical removal: Case report. Neurosurgery 28: 606-609,1991

16. Pencalet $P$, Maixner $W$, Sainte-Rose $C$, Lellouch-Tubiana A, Cinalli G, Zerah M, Pierre-Kahn A, Hoppe-Hirsch E, Bourgeois M, Renier D: Benign cerebellar astrocytomas in children. J Neurosurg 90: 265-273,1999

17. Scheithauer BW, Hawkins C, Tihan T, VandenBerg SR, Burger PC: Pilocytic astrocytoma. In: Louis DN et al. ed WHO Classification of tumours of the central nervous system, 4th edn Lyon: IARC, 2007 14-21

18. Schneider JH Jr, Raffel C, McComb JG: Benign cerebellar astrocytomas of childhood. Neurosurgery 30: 58-63,1992

19. Scott RM, Ballantine HT: Cerebellar astrocytoma. Malignant recurrence after prolonged postoperative survival. Case report. J Neurosurg 39:777-779,1973

20. Sgouros S, Fineron PW, Hockley AD: Cerebellar astrocytoma of childhood: Long-term follow-up. Child's Nerv Syst 11:89-96,1995

21. Smoots DW, Geyer JR, Lieberman DM, Berger MS: Predicting disease progression in childhood cerebellar astrocytoma. Childs Nerv Syst 14(11):636-648,1998

22. Viano JC, Herrera EJ, Suarez JC: Cerebellar astrocytomas: A 24year experience. Child's Nerv Syst 17:607-610,2001

23. Zakrzewski K, Fiks T, Polis L, Liberski PP: Posterior fossa tumors in children and adolescents. A clinicopathological study of 216 cases. Folia Neuropathologica 41(4):251-252,2003 